\title{
Isolated para-aortic lymph node recurrence of a woman with low-grade serous ovarian cancer: The importance of lymphadenectomy
}

\section{Düşük grade seröz over kanseri olan bir kadında izole para-aortik lenf nodu rekürrensi: Lenfadenektominin önemi}

\author{
İbrahim Yalçın, Burak Ersak, Hanifi Şahin, Mustafa Erkan Sarı, Tayfun Güngör \\ Department of Gynecologic Oncology, Zekai Tahir Burak Women's Health Research and Training Hospital, \\ Faculty of Medicine, University of Health Sciences, Ankara, Turkey
}

Dergiye Ulașma Tarihi:27.04.2018 Dergiye Kabul Tarihi:07.09.2018 Doi: 10.5505/aot.2018.60352

\section{ÖZET}

$\mathrm{Bu}$ olgu sunumunda evre I düşük grade seröz over kanseri rekürrensi olan bir kadının ayrıntılarını bildirdik. 72 yaşında bir kadın izole paraaortik lenf nodu rekürrensiyle başvurdu. Hastaya 2015 yılında primer sitoredüktif cerrahi uygulanmıștı. Bu cerrahi esnasında pelvik ve paraaortik lenfadenektomi uygulanmamıștı. Aralık 2017 esnasında uygulanan PET CT görüntülemede belirgin olarak aortokaval alanda paraaortik $2.7 \times 1.8 \mathrm{~cm}$ lenfadenopati gösterildi. Bu olgu sunumunda düşük grade seröz over kanseri yönetiminde sistemik pelvik ve paraaortik lenfadenektominin önemini gösterdik.

Anahtar Kelimeler: Düşük-grade seröz over kanseri, paraaortik lenfadenektomi, rekürrens

\begin{abstract}
In this case report, we reported the details of a woman with stage I low-grade serous ovarian carcinoma recurrence. A 72-year-old woman presented with isolated para-aortic lymph node recurrence. In 2015, she underwent primary cytoreductive surgery. A pelvic/para-aortic lymphadenectomy was not performed during this primary surgery. PET CT Examination on December 2017 clearly demonstrated para-aortic $2.7 \times 1.8 \mathrm{~cm}$ lymphadenopathy in the aortocaval region (SUV max: 24.09). This case report shows that importance of systematic pelvic and para-aortic lymphadenectomy in the management of low-grade serous ovarian cancer.

Keywords: Low-grade serous ovarian cancer, para-aortic lymphadenectomy, recurrence.
\end{abstract}

\section{INTRODUCTION}

Primary cytoreductive (i.e. complete resection without any macroscopic post-operative tumor residuals) surgery has the main role in the management of ovarian cancer (1). Despite the standard surgical treatment, another significant factor positively associated with superior outcome is response to systemic treatment (2).

Low-grade serous ovarian cancer represents a minority within the group of invasive serous tumors of the genital tract. This type of serous ovarian carcinoma harbor different molecular abnormalities and have different clinical courses than high-grade serous carcinoma (3). Especially this difference could be seen in chemotherapy response. It was demonstrated that low-grade serous ovarian cancer is relatively insensitive to chemotherapy (4). Due to the decreased response to the chemotherapy, primary cytoreductive surgery transforms to a more crucial position in the management of lowgrade serous cancer.

LION study reported that systematic pelvic and para-aortic lymphadenectomy did not neither improve overall nor progressionfree survival in advanced ovarian cancer (5). Unfortunately they were unable to analyze only low grade and early stage patients.

In this case we want to demonstrate the importance of retroperitoneal lymphadenectomy in a low-grade ovarian cancer patient who had recurrence only in para-aortic nodal region. 


\section{CASE}

We present a case of a 72 year-old woman who was referred to our hospital from her primary care provider. In 2015, she underwent midline laparotomy for a $15 \times 14 \mathrm{~cm}$ diameter right ovarian cyst. They performed hysterectomy, bilateral salpingo-oophorectomy, omentectomy and appendectomy, frozen pathology was lowgrade serous carcinoma. There was no evidence of peritoneal implantation and enlarged pelvic/paraaortic lymph nodes. A pelvic/para-aortic lymphadenectomy was not performed during this primary surgery. The final pathology examination showed that lowgrade serous carcinoma of the right ovary and there were no infiltration to other dissected uterus, left ovary and omentum. The patient had been managed for FIGO stage IA. Two years after the first operation, recurrence was suspected based on the results of a positron emission tomography/computed tomography (PET/CT) examination. Patient admitted to our outpatient clinic. CA 125 level was increased to $174 \mathrm{U} / \mathrm{ml}$. PET CT Examination clearly demonstrated para-aortic $2.7 \times 1.8 \mathrm{~cm}$ adenopathy in the aortocaval region. Increased FDG uptake was localized in these lymph nodes on the fused PET/CT image (SUV max: 24.09). No other lesions were observed. Patient's physical condition was able to tolerate surgery. We suggest her to perform seconder cytoreductive surgery. Although ovarian cancer recurrence was suspected the patient refused surgical treatment. After refusing surgical treatment, 6 cyles of paclitaxel and carboplatin chemotherapy administration was planned.

\section{DISCUSSION}

In this report we describe the isolated paraaortic lymph node recurrence of a lowgrade serous ovarian cancer patient. Unfortunately the patient denied undergoing for a secondary debulking surgery. Thus we referred the patient to receive chemotherapy.

Independent of the tumor grade in women with ovarian cancer, it is important to achieve an optimal cytoreduction without residual disease (1). This should include at least total abdomin al hysterectomy, bilateral salpingo-oophorectomy, omentectomy, lymph node resection, and resection of all visible macroscopic disease. As our knowledge lymphadenectomy and survival for low-grade serous ovarian cancer patients has not been previously reported.

Several authors reported different survival outcomes of lymph node resection in ovarian cancer surgery. Panici et al. demonstrated that systematic lymphadenectomy improves progression-free but not overall survival in women with optimally debulked advanced ovarian carcinoma (6). On the other hand du Bois et al. reported that ovarian cancer patients with and without lymphadenectomy, the median survival time was 103 and 84 months, respectively, and 5-year survival rates were 67 $\%$ and $59.2 \%$, respectively $(\mathrm{p}=.0166)(7)$. Additionally, Chan et al. suggested that an extensive lymph node resection may lead to an improvement in survival by removing micrometastatic disease within the lymph nodes that may be resistant to chemotherapy (8). Although a recent prospective randomized study from Harter et al. (LION study) reported that systematic pelvic and para-aortic lymphadenectomy did not neither improve overall nor progression-free survival in advanced ovarian cancer, a large epidemiologic study based on the Surveillance, Epidemiology, and End Results (SEER) database suggested that women with stage I non-clear cell ovarian cancers who underwent lymphadenectomy had a significant improvement in survival (9). Also, It should be noted that in the LION trial early stage patients have not been inclued in the study and no analysis was performed according to tumor grade.

To date only one author reported isolated lymph node recurrence recurrence of low-grade serous ovarian cancer (10). But, both the stage and the recurrent lymph node region of low-grade serous ovarian cancer have not been described in detail. When they looked at the whole study group (73 patients,) isolated lymph node recurrence was higher $(75.4 \%)$ in the patients who were not undergone systematic lymphadenectomy during initial surgery.

This case report shows that importance of systematic pelvic and para-aortic lymphadenectomy in the management of lowgrade serous ovarian cancer. In view of the fact that low-grade serous ovarian cancer is less 
sensitive to platinum based chemotherapy (4), it would be more appropriate to perform systematic pelvic and para-aortic lymphadenectomy during the initial surgery.

Conflict of interest: The authors declare that they have no conflict of interest

\section{REFERENCES}

1. du Bois A, Reuss A, Pujade-Lauraine E, Harter P, Ray-Coquard I, Pfisterer J. Role of surgical outcome as prognostic factor in advanced epithelial ovarian cancer: a combined exploratory analysis of 3 prospectively randomized phase 3 multicenter trials: by the Arbeitsgemeinschaft Gynaekologische Onkologie Studiengruppe Ovarialkarzinom (AGOOVAR) and the Groupe d'Investigateurs Nationaux Pour les Etudes des Cancers de l'Ovaire (GINECO). Cancer. 2009;115(6):1234-44.

2. Katki HA, Schiffman M, Castle PE, et al. Five-year risks of CIN 2+ and CIN 3+ among women with HPV-positive and HPV-negative LSIL Pap results. J Low Genit Tract Dis. 2013;17(5 Suppl 1):S43-9.

3. Meinhold-Heerlein I, Bauerschlag D, Hilpert F, et al. Molecular and prognostic distinction between serous ovarian carcinomas of varying grade and malignant potential. Oncogene. 2005;24(6):105365.

4. Gershenson DM, Sun CC, Bodurka D, et al. Recurrent low-grade serous ovarian carcinoma is relatively chemoresistant. Gynecol Oncol. 2009;114(1):48-52.

5. Harter P, Sehouli J, Lorusso D, et al. LION: Lymphadenectomy in ovarian neoplasms-A prospective randomized AGO study group led gynecologic cancer intergroup trial. Journal of Clinical Oncology. 2017;35(15_suppl):5500-.

6. Panici PB, Maggioni A, Hacker N, et al. Systematic aortic and pelvic lymphadenectomy versus resection of bulky nodes only in optimally debulked advanced ovarian cancer: a randomized clinical trial. J Natl Cancer Inst. 2005;97(8):560-6.

7. du Bois A, Reuss A, Harter P, et al. Potential role of lymphadenectomy in advanced ovarian cancer: a combined exploratory analysis of three prospectively randomized phase III multicenter trials. J Clin Oncol. 2010;28(10):1733-9.

8. Chan $\mathrm{J}$, Urban $\mathrm{R}$, $\mathrm{Hu} \mathrm{J}$, et al. The potential therapeutic role of lymph node resection in epithelial ovarian cancer: a study of 13918 patients. British journal of cancer. 2007;96(12):1817.

9. Chan JK, Munro EG, Cheung MK, et al. Association of lymphadenectomy and survival in stage I ovarian cancer patients. Obstetrics \& Gynecology. 2007;109(1):12-9.

10. Ferrero A, Ditto A, Giorda G, et al. Secondary cytoreductive surgery for isolated lymph node recurrence of epithelial ovarian cancer: a multicenter study. Eur J Surg Oncol. 2014;40(7):891-8. 